Check for updates

Cite this: RSC Adv., 2019, 9, 21095

\title{
Synthesis and appraisal of a hydroxyapatite/pectin hybrid material for zinc removal from water $\dagger$
}

\begin{abstract}
Pan Ni and John T. Fox (iD *
A simple method to modify hydroxyapatite and pectin into an efficient zinc sorbent was investigated. Process and formulation modifications enabled the formation of a flower-like hydroxyapatite/pectin hybrid material. The hybrid material was characterized with scanning electron microscopy, elemental analysis, and zeta potential tests. Sorption data were analyzed with different kinetic and isotherm models. The results showed that the pseudo-second order kinetic model and two-staged isotherm curves with Langmuir at the first stage and a Freundlich model the at second stage could best describe the zinc sorption on the hybrid. The maximum experimental sorption capacity was $330.4 \mathrm{mg} \mathrm{Zn}^{2+}$ per gram of sorbent, which was obtained with an initial concentration of $260 \mathrm{mg} \mathrm{L}^{-1} \mathrm{Zn}^{2+}$ at pH 5.0. pH monitoring and Zeta potential tests suggested surface complexation and electrostatic attraction were fundamental in the zinc sorption process.
\end{abstract}

Received 16th May 2019

Accepted 29th June 2019

DOI: 10.1039/c9ra03710a

rsc.li/rsc-advances

with that of the precursor material of needle-like HAP $(83 \mathrm{mg}$ $\mathrm{g}^{-1}$ ). The advantage of their modification as they emphasized in the article, was lower $\mathrm{Ca}^{2+}$ leaching and thus less concern on water hardness. Other researchers use biological molecules, such as chitosan or amino-phosphate molecules to modify HAP in order to form new composites for metal removal from water. ${ }^{\mathbf{8} 14}$ It was reported that composite sorbents made via in situ incorporation of $2.5 \mathrm{wt} \%$ nitrilotris (methylene) triphosphonic acid (NTP) molecules in the HAP, demonstrated better $\mathrm{Zn}^{2+}$ and, $\mathrm{Pb}^{2+}$ sorption than HAP alone, as the capacity was increased by $30.7 \%$ for $\mathrm{Zn}^{2+}$ and $47.5 \%$ for $\mathrm{Pb}^{2+}$. The material property enhancement attributed with the performance improvement was increased surface area, which increased from $120 \mathrm{~m}^{2} \mathrm{~g}^{-1}$ to $160 \mathrm{~m}^{2} \mathrm{~g}^{-1}$, and the external phosphate groups enhanced by NTP. However, the maximum capacity of the composite was obtained when $10 \mathrm{wt} \%$ NTP was used, yet the surface area was $23.3 \%$ lower than the synthesized HAP. ${ }^{14}$ One potential concern with the modification is that the additive, NTP, is an amino-phosphate compound and may cause eutrophication if leached to surface waters.

Compared to NTP or chitosan, pectin is an alternative biomaterial for HAP modification, which is available at a low cost; possesses high levels of oxygen enriched groups like $-\mathrm{OH}$ and $-\mathrm{COOH}$; and poses negligible environmental risk. ${ }^{15,16}$ Previously, Gong et al. ${ }^{17}$ synthesized a $\mathrm{Fe}_{3} \mathrm{O}_{4}$-pectin composite by a simple iron salt co-precipitation method for copper removal. The maximum adsorption capacity was $48.99 \mathrm{mg} \mathrm{g}^{-1}$. Since higher $\mathrm{pH}$ promoted $\mathrm{Cu}^{2+}$ adsorption and a decrease in $\mathrm{pH}$ followed copper uptake, electrostatic forces and ion exchange were determined to drive the adsorption process. ${ }^{17}$ As to the investigations of pectin, collagen or chitosan HAP based material, many studies focused on the medical field

Department of Civil and Environmental Engineering, Lehigh University, 1 West Packer Avenue, Bethlehem, PA 18015, USA. E-mail: jtf211@lehigh.edu; Tel: +1-610-758-2593 $\dagger$ Electronic supplementary information (ESI) available. See DOI: 10.1039/c9ra03710a 
applications such as bone tissue scaffold development, ${ }^{9}$ drug delivery, cell immobilization, ${ }^{\mathbf{1 8 , 1 9}}$ anti-bacteria material ${ }^{\mathbf{2 0}}$ or even the crystal growth affection of HAP itself. ${ }^{15}$ As far as we know, no one applied pectin modified HAP in zinc removal.

In the present work, a novel HAP/pectin hybrid material was developed as a metal sorbent for water treatment. The metal sorption ability of the hybrid was tested and compared with the precursor materials of pectin and HAP. Herein, $\mathrm{Zn}^{2+}$ was selected as the target heavy metal since it was well reported that zinc ions are more difficult to remove than $\mathrm{Cu}^{2+}, \mathrm{Pb}^{2+}, \mathrm{Cd}^{2+}$ by various adsorbents, including moss, peat, hydrous manganese oxide nanoparticles, activated carbon, activated phosphate rock and soil. The challenge with zinc removal is due to the small ionic radius, low electronegativity and classification of a borderline Lewis acid..$^{21-25}$

\section{Experiments}

\subsection{Materials}

The powder hydroxyapatite $(34-40 \% \mathrm{Ca}), \mathrm{NaOH}$ pellets $(98 \%)$ were purchased from Alfa Aesar (Haverhill, MA). $\mathrm{KNO}_{3}(\geq 99 \%)$ and $\mathrm{ZnCl}_{2}(98.7 \%)$ were purchased from Fisher Scientific (Hampton, NH). Nitric acid (65\%, $2.5 \mathrm{~L})$ was purchased from EMD Millipore (Burlington, MA). Pectin derived from citrus peels, containing galacturonic acid $\geq 74.0 \%$, was purchased from Sigma-Aldrich (St. Louis, MO). Ethanol, 190 Proof, was purchased from VWR (Radnor, PA).

\subsection{Preparation of the HAP/pectin hybrid}

$\mathrm{HAP} /$ pectin hybrids were synthesized by measuring 3 grams of HAP, which was added into $30 \mathrm{~mL}$ deionized water. Then, $65 \%$ $\mathrm{HNO}_{3}$ was added dropwise to dissolve the HAP. After the HAP was completely dissolved and the solution became transparent, $100 \mathrm{~mL}$ of $0.5 \%(\mathrm{w} / \mathrm{v})$ pectin was added and mixed with a magnetic stirrer for 10 minutes. The pectin solution was prepared by heating the mixture at $60{ }^{\circ} \mathrm{C}$ for 2 hours. Then the resulting mixture was precipitated with concentrated $\mathrm{NaOH}(2$ M) at pH 10, leading to a milk-like suspension. Subsequently, the suspension was added dropwise into $300 \mathrm{~mL}$ ethanol (95\%, 190 proof), filtered and dried at $60{ }^{\circ} \mathrm{C}$ for 12 hours. This synthesized hybrid was rinsed using deionized water to wash off the residual $\mathrm{NaOH}$ until the $\mathrm{pH}$ of the rinsing water was neutral, and was once-again filtered and dried at $60^{\circ} \mathrm{C}$ in the oven for 24 hours. Finally, the HAP/pectin hybrid materials were ground and sieved via no. 200 mesh sieve for further use (the commercial HAP was sieved in the same way).

\subsection{Characterization methods}

The surface zeta potential of HAP/pectin hybrids were appraised under a range of $\mathrm{pH}$ conditions, as described elsewhere, ${ }^{\mathbf{2 6}}$ by using a Malvern Zeta-Sizer. Specifically, the suspensions were prepared by adding 0.05 grams of adsorbent into $100 \mathrm{~mL}$ of $1 \mathrm{mM} \mathrm{KNO}_{3}$ solution. The suspensions were ultra-sonicated for 2 minutes, then the suspensions were aged for 12 hours at ambient temperature. The $\mathrm{pH}$ was then adjusted to the desired set-points, ranging from 4.5 to 10.0. Subsequently, those suspensions were aged for $30 \mathrm{~min}$ and the zeta potential of each samples were tested immediately after the $\mathrm{pH}$ was tested (the $\mathrm{pH}$ tested here was used as the final $\mathrm{pH}$ ). The morphology and elemental analysis studies of all adsorbent samples were carried out by utilizing the Phenom XL Scanning Electron Microscope (SEM) equipped with an Energy Dispersive X-ray detector (EDX). The instrument was operated under high vacuum with a backscatter electron detector (BSD). The accelerating voltage was set to $15 \mathrm{kV}$ throughout the analysis. The surface area was quantified by Micromeritics ASAP 2020 based on $\mathrm{N}_{2}$ adsorption/ desorption isotherms collected at $87 \mathrm{~K}$ using the BET method. Fourier transformed infrared spectroscopy (FT-IR) of the adsorbents were collected using a Thermo-Scientific ${ }^{\mathrm{TM}}$ Nicolet $^{\mathrm{TM}}$ iS 10 FT-IR spectrometer scanning between 650$4000 \mathrm{~cm}^{-1}$. The powder samples were oven dried at $80{ }^{\circ} \mathrm{C}$ for 12 hours before analysis. The X-ray diffraction (XRD) analysis was performed by using Rigaku MiniFlex II diffractometer with graphite monochromatized $\mathrm{Cu}-\mathrm{K} \alpha$ radiation $(\lambda=1.5406 \AA)$ under $30 \mathrm{kV}, 15 \mathrm{~mA}$ and scanning between $10^{\circ}$ to $70^{\circ}(2 \theta)$ with a step of $0.02^{\circ}$. The identification of crystalline phases was determined by MDI Jade 6 (Materials Data Inc.).

\subsection{Sorption studies}

Batch tests were performed to determine the kinetics of the sorption. Specifically, $1.0 \mathrm{~L}$ of $180 \mathrm{mg} \mathrm{L}^{-1} \mathrm{Zn}^{2+}$ solution was prepared and adjusted to $\mathrm{pH} 5.0$ with $1 \mathrm{M} \mathrm{HNO}_{3}$. At time zero, 0.5 grams of adsorbent was added to the solution. The mixture was then placed in a New Brunswick Scientific incubator shaker at $25 \pm 1{ }^{\circ} \mathrm{C}$, set to a mixing speed of $200 \mathrm{rpm}$. At desired time intervals a $10 \mathrm{~mL}$ sample solution was withdrawn from the $1.0 \mathrm{~L}$ solution at $5 \mathrm{~min}, 15 \mathrm{~min}, 30 \mathrm{~min}, 1 \mathrm{~h}, 3 \mathrm{~h}, 6 \mathrm{~h}, 12 \mathrm{~h}, 24 \mathrm{~h}$, and $48 \mathrm{~h}$. The samples were then filtered with $0.45 \mu \mathrm{m}$ glass fiber filters and analyzed by a PerkinElmer Analyst 200 AAS. The reproducibility of the zinc concentration was ensured by repeating the experiments twice, and the average values are reported herein.

The sorption capacity was appraised experimentally by placing $50 \mathrm{mg}$ of adsorbents in a $250 \mathrm{~mL}$ conical flask containing $100 \mathrm{~mL}$ of the desired zinc solution. The samples were placed in a New Brunswick Scientific incubator shaker at $25 \pm$ $1{ }^{\circ} \mathrm{C}$ with a rotation speed set at $200 \mathrm{rpm}$. The zinc solution was designed to start at concentrations ranging from 40 to $260 \mathrm{mg} \mathrm{L}^{-1}$ of $\mathrm{Zn}^{2+}$ (40-180 $\mathrm{mg} \mathrm{L}^{-1}$ for the commercial HAP, 120-260 $\mathrm{mg} \mathrm{L}^{-1}$ for the HAP/pectin hybrid), and the $\mathrm{pH}$ was adjusted to 5.0 using $1 \mathrm{M} \mathrm{HNO}_{3}$. The authors utilized nine different concentrations for each isotherm. After 48 hours of treatment, the adsorbents were separated from the solution using a $0.45 \mu \mathrm{m}$ glass fiber filter. At equilibrium, both the zinc concentrations and $\mathrm{pH}$ were measured by a PerkinElmer Analyst 200 AAS and pH meter. The isotherms were modeled by utilizing the initial zinc concentration, the equilibrium zinc concentration, the liquid volume, the mass of adsorbent, and were then fit to the Langmuir (eqn (1)), Freundlich (eqn (2)), and Temkin (eqn (3)) isotherm equations:

$$
q_{\mathrm{e}}=\frac{q_{\mathrm{m}} k C_{\mathrm{e}}}{1+k C_{\mathrm{e}}}
$$




$$
\begin{gathered}
q_{\mathrm{e}}=K_{\mathrm{f}} C_{\mathrm{e}}^{n} \\
q_{\mathrm{e}}=\frac{R T}{b} \ln \left(K_{\mathrm{T}} C_{\mathrm{e}}\right)
\end{gathered}
$$

The reproducibility in the zinc concentration and $\mathrm{pH}$ measurements was ensured by repeating the experiments twice, and the average values are reported.

\section{Results and discussion}

\subsection{Synthesis optimization}

Our preliminary work demonstrated that the HAP/pectin hybrid material performed better in aqueous zinc removal than the precursor materials, HAP or pectin. As is illustrated in Fig. 1, after 48 hours treatment, 1 gram of HAP can remove $42.1 \pm$ $7.5 \mathrm{mg}$ of $\mathrm{Zn}^{2+}$ while pectin removed a comparable amount at $44.4 \pm 2.2 \mathrm{mg}$ of $\mathrm{Zn}^{2+}$. These results were consistent with the previous investigations on $\mathrm{HAP}^{6,11,27}$ and pectin. ${ }^{2,29}$ However, under the same experimental conditions, the capacity of five different HAP/pectin hybrids averaged more than $225 \mathrm{mg} \mathrm{Zn}^{2+}$ per gram of adsorbent. By adjusting the mass ratio of HAP and pectin; and modifying the synthesis procedure (with or without ethanol dehydration treatment), the best performing hybrid (6H1P) achieved $285.6 \pm 3.3 \mathrm{mg} \mathrm{Zn}^{2+}$ per gram of hybrid adsorbent.

\subsection{XRD analysis}

XRD patterns are displayed in Fig. 2, for the native HAP, compared to the synthesized HAP/pectin hybrid powders. As is shown in HAP's diffractogram, the typical diffraction peaks at $26^{\circ}, 32^{\circ}, 33^{\circ}, 34^{\circ}$ and $64^{\circ}$ corresponding to the HAP structure were detected (JCPDS no. 09-0432). The strong and sharp peaks suggested that HAP was well crystallized. For the hybrid material, a mixture of three calcium phosphates: HAP, brushite $\left(\mathrm{CaPO}_{3}(\mathrm{OH}) \cdot 2 \mathrm{H}_{2} \mathrm{O}\right)$ and monetite $\left(\mathrm{CaPO}_{3}(\mathrm{OH})\right)$ were confirmed

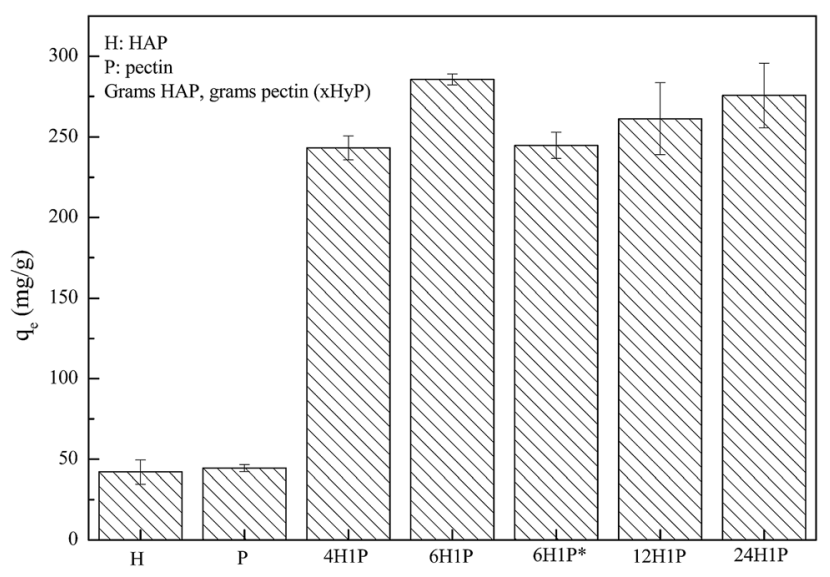

Fig. $1 \mathrm{HAP} /$ pectin hybrid materials compared to precursor materials, when $0.5 \mathrm{~g} \mathrm{~L}^{-1}$ of adsorbents were used to treat $180 \mathrm{mg} \mathrm{L}^{-1} \mathrm{Zn}^{2+}$ at $\mathrm{pH}$ 5.0. The mass ratio of each sample is provided, $6 \mathrm{H} 1 \mathrm{P}$ used 6 grams of HAP and 1 gram of pectin (*denotes there was no pretreatment by ethanol before drying).

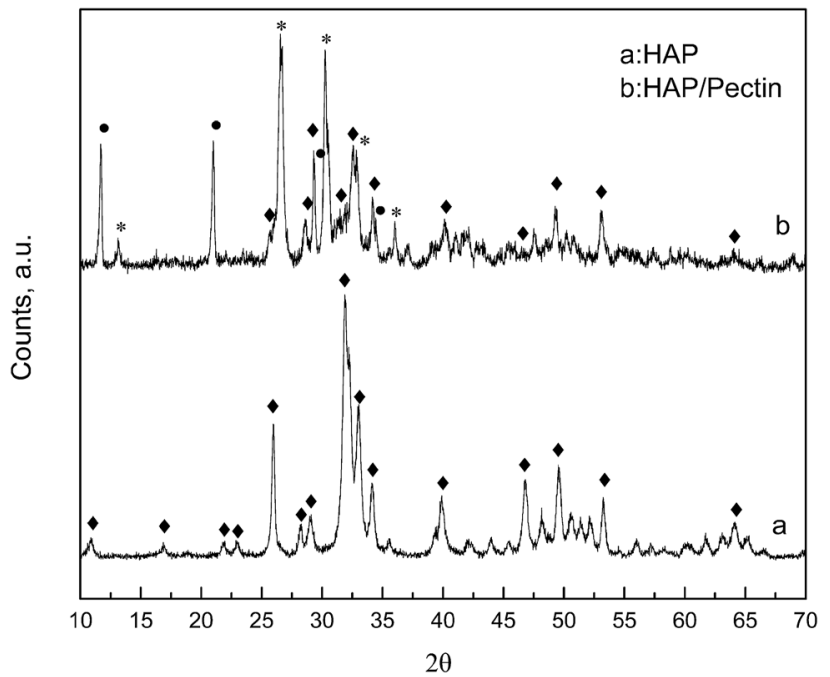

Fig. 2 XRD patterns of HAP and optimized HAP/pectin hybrid. Principal diffractions of $\mathrm{HAP}(\bullet) ; \mathrm{CaPO}_{3}(\mathrm{OH}) \cdot 2 \mathrm{H}_{2} \mathrm{O}(\mathrm{O}) ; \mathrm{CaPO}_{3}(\mathrm{OH})(*)$.

based on MDI Jade 6 database. It's reported that the brushite and monetite are common impurities in the synthesis of HAP under mild conditions. ${ }^{30}$ The peaks standing for HAP became significantly short and broadened indicating a less crystalized status. The low temperature used to dry the material $\left(60^{\circ} \mathrm{C}\right)$ as well as the introduction of organic molecules (pectin) may contribute to this phenomenon. Saoiabi et al. ${ }^{31}$ reported a similar crystallinity decrease when they used nitrilotris (methylene) triphosphonic acid as an additive in their HAP modification process. However, the principal peaks at $11.8^{\circ}$, $21^{\circ}, 29^{\circ}, 35^{\circ}$ standing for brushite (JCPDS no. 09-0077) and those at $13^{\circ}, 26.5^{\circ}, 30^{\circ}, 33^{\circ}, 36^{\circ}$ standing for monetite (JCPDS no. 09-0080) were pretty strong and sharp in our case, indicating a high crystallinity inside these two phosphates, brushite and monetite.

\subsection{FTIR analysis}

The recorded FTIR spectra of HAP and HAP/pectin hybrid are shown in Fig. 3 in the wavelength range $650-4000 \mathrm{~cm}^{-1}$. The broad and not intense $\mathrm{O}-\mathrm{H}$ stretching band in the region 3550$3400 \mathrm{~cm}^{-1}$ is caused by the presence of lattice water in the solid. ${ }^{32}$ The bands corresponding to the vibration of carbonate was observed in both HAP and HAP/pectin powder. For the HAP, the carbonate impurities is likely to cause the broad pit at 1485 , $1686 \mathrm{~cm}^{-1}$ (ref. 10) and is reflected by the floating mass ratio of calcium (34-40\%) in the commercial product. For the hybrid, the characteristic pits of carbonate group at $866,890 \mathrm{~cm}^{-1}$ (ref. 10 and 32) was suggested to be caused in the hybrid synthesis procedure when $2 \mathrm{M}$ of $\mathrm{NaOH}$ was used to promote the precipitation of HAP, inducing $\mathrm{CO}_{2}$ absorption from the atmosphere. ${ }^{33}$ The band at $1267 \mathrm{~cm}^{-1}$ was likely derived from $\mathrm{HPO}_{4}{ }^{2-} \cdot{ }^{34}$ The pits at 1088, 1021, $962 \mathrm{~cm}^{-1}$ for HAP and the $1130,1062,973 \mathrm{~cm}^{-1}$ for the hybrid were suggested to be the typical bands of $\mathrm{PO}_{4}{ }^{3-} \cdot{ }^{35}$ It should be noted that a $11-42 \mathrm{~cm}^{-1}$ blue shift of $\mathrm{PO}_{4}{ }^{3-}$ pits occurred when $\mathrm{HAP} /$ pectin hybrid was compared with HAP, indicating a possible strong interaction 


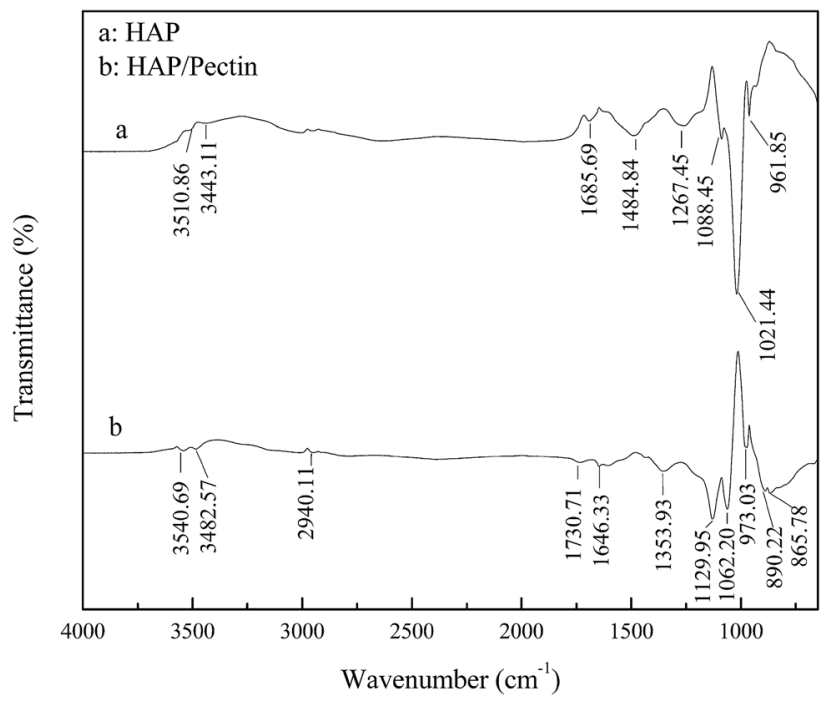

Fig. 3 FTIR spectrum of HAP and HAP/pectin hybrid.

between HAP and pectin inside the hybrid..$^{36}$ Previously, Fu et al. ${ }^{37}$ reported the strong chemisorption of tartaric acid toward HAP via carboxylic acid groups chelating with calcium from HAP. Since the pectin used in our HAP/pectin hybrid contains galacturonic acid $\geq 74.0 \%$, a similar process was expected to occur in this case. Moreover, the alkyl $\left(-\mathrm{CH}_{n}\right)$ pit at $2940 \mathrm{~cm}^{-1}$, carboxylate (COO-) pits at 1354, $1646 \mathrm{~cm}^{-1}$, carboxyl-ester (COOR) pit at $1731 \mathrm{~cm}^{-1}$ were detected, ${ }^{37,38}$ indicating the successful loading of the pectin onto the HAP.

\subsection{SEM-EDX analysis}

The HAP and HAP/pectin hybrid powder were examined by SEM. Significant differences in morphology were observed. For commercial HAP, spherical-like aggregates with diameters less than $30 \mu \mathrm{m}$ were exhibited in Fig. $4 \mathrm{~A}$ and B. The HAP/pectin hybrid appeared as large flower-like particles consisting of sheet-like subunits ( $\sim 650 \mathrm{~nm}$ in thickness). As is illustrated in Fig. $4 \mathrm{D}$ and $\mathrm{E}$, the size of the hybrid is larger than that of the HAP. Some of the hybrid particles were larger than $60 \mu \mathrm{m}$ in diameter.

Elemental mapping by EDX was also performed and repeated on 10 different particles of HAP or hybrid. In all cases, EDX analysis showed the presence of $\mathrm{Ca}, \mathrm{O}, \mathrm{C}, \mathrm{P}, \mathrm{K}$ (Table 1 and Fig. $4 \mathrm{C}$ and $\mathrm{F}$ ). The atomic ratio of $\mathrm{Ca}$ to $\mathrm{P}$ on the surface of the materials was 2.1 for HAP and 1.3 for the hybrid, indicating impurities inside the adsorbents based on the stoichiometric ratio of $\mathrm{Ca}$ to $\mathrm{P}(1.67)$ in the hydroxyapatite.$^{39}$ The detected carbonate bands by FTIR spectrum shown in Fig. 3 may explain

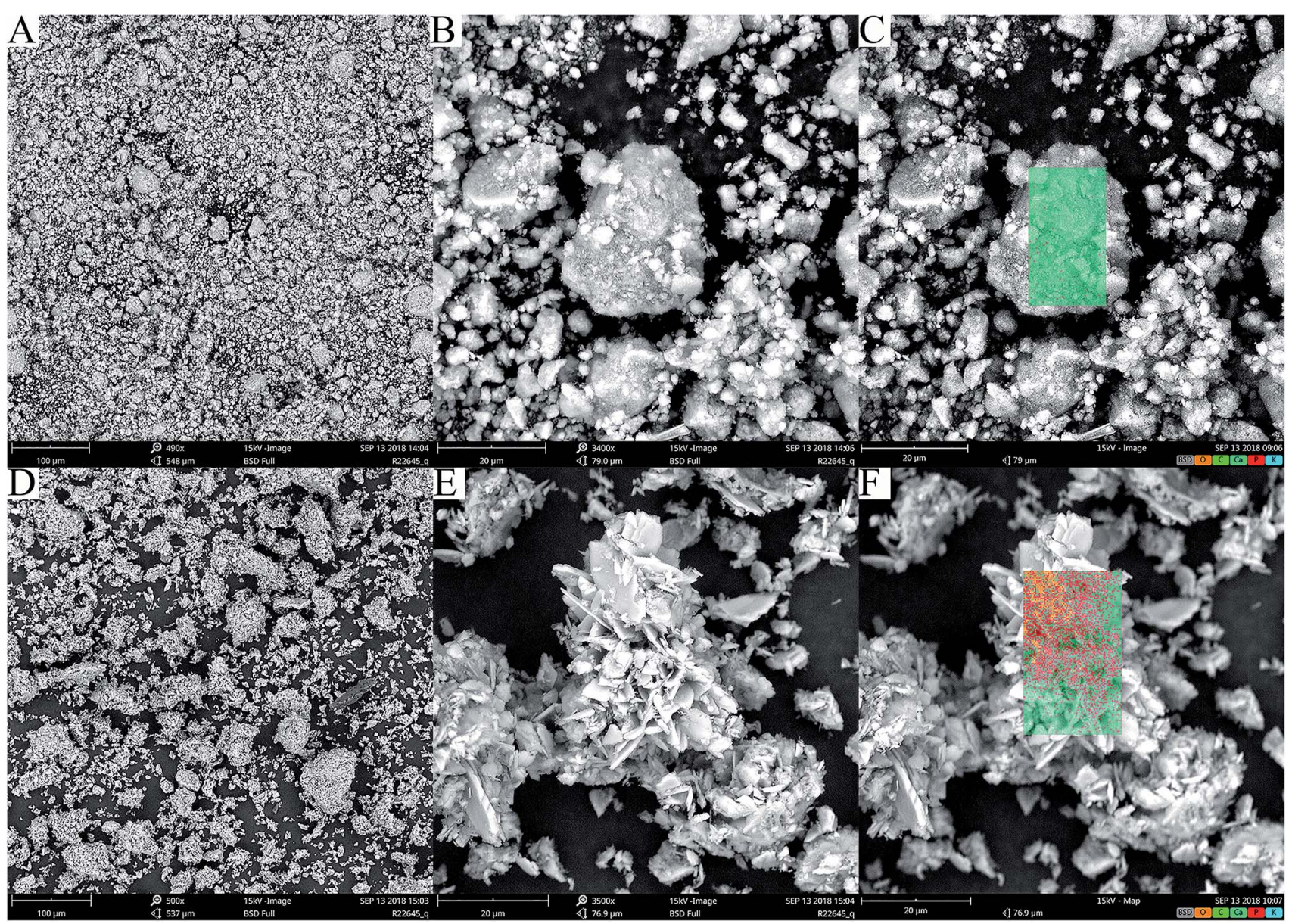

Fig. 4 SEM images of HAP (A and B); and HAP/pectin hybrids ( $\mathrm{D}$ and $\mathrm{E})$, with elemental mapping by EDX detector was shown in (C) HAP and (F) $\mathrm{HAP} /$ pectin. 
Table 1 Elemental analysis of HAP and HAP/pectin hybrid powder obtained by EDX

\begin{tabular}{|c|c|c|c|c|c|c|}
\hline Adsorbents & \multicolumn{6}{|l|}{ Atomic\% } \\
\hline HAP/pectin & $12.9 \pm 2.7$ & $54.3 \pm 3.6$ & $23.1 \pm 2.0$ & $9.7 \pm 2.6$ & $0.03 \pm 0.01$ & $1.3 \pm 0.1$ \\
\hline
\end{tabular}

the higher $\mathrm{Ca} / \mathrm{P}$ ratio inside the $\mathrm{HAP}$ since the existence of $\mathrm{CaCO}_{3}$ will absolutely increase the ratio. Sebei et al. ${ }^{39}$ reported a similar result caused by calcium carbonate in the synthesized HAP. For the low atomic ratio of $\mathrm{Ca}$ to $\mathrm{P}$ in the hybrid, the reason may be related to the phosphate impurities detected by XRD (see Fig. 2). The stoichiometric ratio of $\mathrm{Ca} / \mathrm{P}$ in brushite and monetite is 1 while that of HAP is 1.67. Based on atomic ratio of $\mathrm{Ca}$ to $\mathrm{P}$ in hybrid shown in Table 1 , the chemical components composition can be calculated with the hybrid containing $44.8 \%$ HAP and $55.2 \%$ brushite \& monetite. Previously, Minh et al. ${ }^{30}$ also observed the similar low $\mathrm{Ca} / \mathrm{P}$ atomic ratio on the surface of their synthesized HAP and suggested the reason was related to the existence of brushite and monetite.

Additionally, compared to the HAP, the carbon and oxygen atomic level in the hybrid was higher (Table 1). Possible reasons that may contribute to the higher carbon and oxygen levels include the formation of carbonate via $\mathrm{CO}_{2}$ absorption from the atmosphere in the synthesis of HAP/pectin hybrid; and the loading of pectin onto the HAP. Based on the fact that $\mathrm{O}$ increased by $2 \%$ and $\mathrm{C}$ increased by $2.3 \%$, the loading of pectin is more likely to be the reason since pectin with a low esterification can induce equivalent atomic increase of element $\mathrm{C}$ and $\mathrm{O}$ when pectin's fundamental unit $\mathrm{C}_{6} \mathrm{O}_{6}$ was considered. ${ }^{15}$ The rest of the carbon detected in both HAP and the hybrid was likely from carbonate impurities based on the FTIR analysis.

\subsection{Sorption kinetics}

The amount of $\mathrm{Zn}^{2+}$ adsorbed onto HAP and HAP/pectin hybrid as a function of time at $\mathrm{pH}$ 5.0, at an initial zinc concentration of $180 \mathrm{mg} \mathrm{L}^{-1}$, is illustrated in Fig. 5A. The figure demonstrates a sharp sorption increase in both adsorbents within the first hour, then the sorption rate slowed down until pseudo equilibrium after 48 hours. It is noteworthy that the zinc sorption ability of the hybrid was more than 6 times as much as that of its parental HAP, indicating the effectiveness of the modification process.

In order to gain insight into the $\mathrm{Zn}^{2+}$ sorption rate and the potential rate-controlling steps, the modified pseudo first and second order models $\mathrm{s}^{\mathbf{4 0 , 4 1}}$ were employed to fit the sorption data shown in Fig. 5A.

For the pseudo first order model:

$$
\ln \left(q_{\mathrm{e}}-q_{t}\right)=\ln q_{\mathrm{e}}-k_{1} t
$$

For the pseudo second order model:

$$
\frac{t}{q_{t}}=\frac{1}{k_{2} q_{\mathrm{e}}^{2}}+\frac{t}{q_{\mathrm{e}}}
$$

where $q_{\mathrm{e}}$ and $q_{t}$ is the amount of $\mathrm{Zn}^{2+}$ adsorbed on the adsorbents $\left(\mathrm{mg} \mathrm{g}^{-1}\right)$, at equilibrium $\left(q_{\mathrm{e}}\right)$ and at time $t\left(q_{t}\right), t$ is the contact time, $k_{1}$ and $k_{2}$ are the rate constants, units are $\mathrm{h}^{-1}$ for $k_{1}$ and $\mathrm{g}\left(\mathrm{mg}^{-1} \mathrm{~h}^{-1}\right)$ for $k_{2}$. Another commonly used parameter is $h$, which is called the initial sorption rate and defined as $h=$ $k_{2} q_{\mathrm{e}}^{2} \cdot{ }^{39,42}$

As is shown in Table 2 , the correlation coefficient $\left(R^{2}\right)$ values of pseudo second order were 0.998 for HAP and 0.999 for the hybrid while those of the pseudo first order were 0.893 for HAP and 0.904 for the hybrid, which is also visually apparent in the difference between Fig. 5B compared to Fig. 5C improved fit. Additionally, the calculated $q_{\mathrm{e}}$ via pseudo second order $(49.4 \mathrm{mg}$ $\mathrm{g}^{-1}$ for HAP, $303.0 \mathrm{mg} \mathrm{g}^{-1}$ for the hybrid) were much closer to the actual experimental ones than those derived from the pseudo first order model. The zinc sorption by HAP and HAP/ pectin matches pseudo second order kinetics, indicating that chemisorption is the rate controlling step and more than onestep may be involved in the sorption processes. ${ }^{42,43}$ The initial sorption rate was $61.50\left(\mathrm{mg}\left(\mathrm{g}^{-1} \mathrm{~h}^{-1}\right)\right)$ for HAP and $353.4(\mathrm{mg}$ $\left.\left(\mathrm{g}^{-1} \mathrm{~h}^{-1}\right)\right)$ for the hybrid, consistent with observations from Fig. 5A where more than half of the $\mathrm{Zn}^{2+}$ adsorbed within the first hour. Also, the much higher capacity of HAP/pectin than that of HAP is apparent. Adsorbents with higher sorption capacities often have lower $k_{2}$ values. ${ }^{41}$

The performance of the HAP/pectin hybrid in this work with other HAP or pectin-based adsorbents in the literature for the removal of $\mathrm{Zn}^{2+}$ is provided in Table 3. As shown, the pectin modified HAP in this work has a higher capacity than most of the adsorbents reported, with the exception of nitrilotris (methylene) triphosphonic acid (NTP) modified natural phosphate which reported a $300.7 \mathrm{mg} \mathrm{g}^{-1}$ experimental capacity toward $\mathrm{Zn}^{2+} \cdot{ }^{31}$ It should be noted, however, that pectin used is lower cost than that of NTP.

\subsection{Sorption isotherms}

In this case, the Langmuir (eqn (6)), Freundlich (eqn (7)) and Temkin isotherm models (eqn (8)) ${ }^{\mathbf{4 7 , 4 8}}$ were adopted to analyze the experimental data, and the results are provided in Fig. 6 and Table 4.

$$
\begin{gathered}
\frac{1}{q_{\mathrm{e}}}=\frac{1}{q_{\mathrm{m}} k C_{\mathrm{e}}}+\frac{1}{q_{\mathrm{m}}} \\
\ln q_{\mathrm{e}}=\ln k_{\mathrm{f}}+n \ln C_{\mathrm{e}} \\
q_{\mathrm{e}}=\frac{R T}{b} \ln k_{\mathrm{T}}+\frac{R T}{b} \ln C_{\mathrm{e}}
\end{gathered}
$$



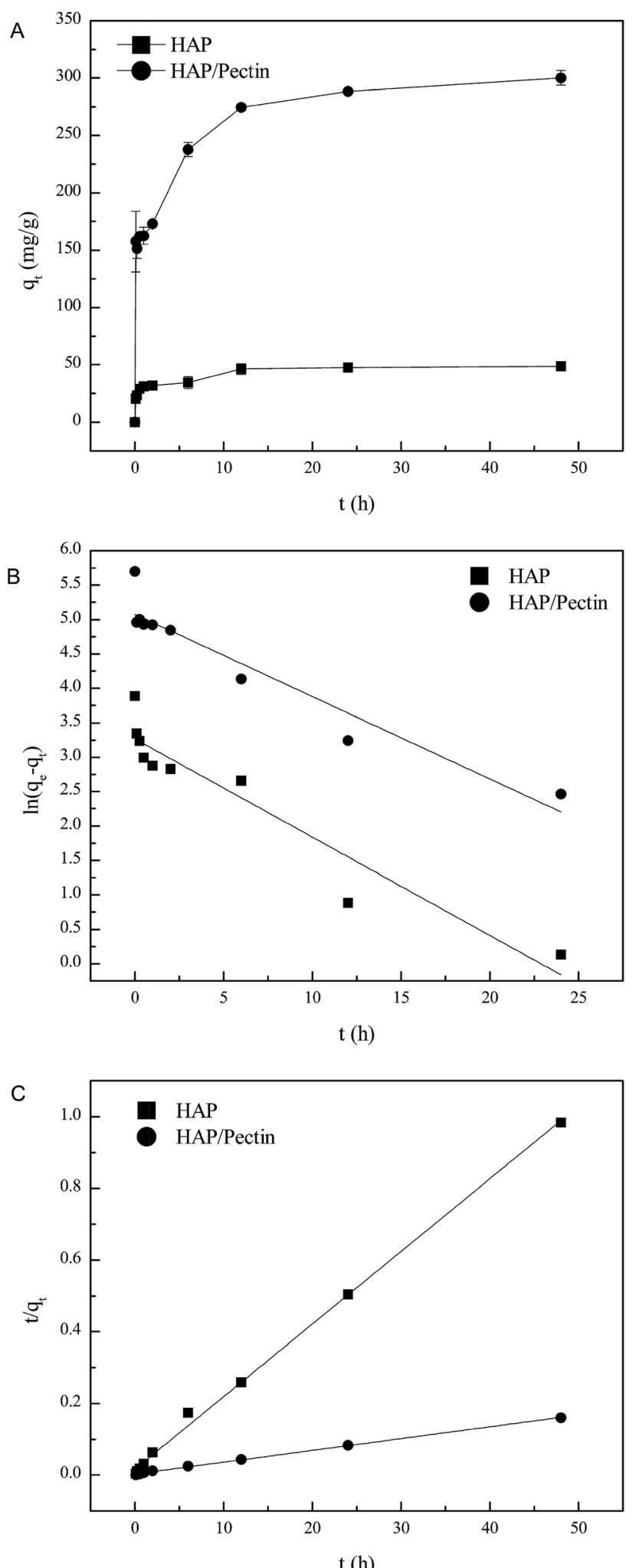

$\mathrm{t}(\mathrm{h})$

Fig. 5 (A) Adsorbed zinc as a function of time, (B) linear fit using pseudo-first order model and (C) linear fit using pseudo-second order model.

The equilibrium concentration is $C_{\mathrm{e}}\left(\mathrm{mg} \mathrm{\textrm {L } ^ { - 1 }}\right), q_{\mathrm{e}}$ is the equilibrium adsorption capacity $\left(\mathrm{mg} \mathrm{g}^{-1}\right), q_{\mathrm{m}}$ is the maximum adsorption capacity $\left(\mathrm{mg} \mathrm{g}^{-1}\right), k$ is a Langmuir constant $\left(\mathrm{L} \mathrm{mg}^{-1}\right)$ related to binding energy and affinity toward adsorbate of the sorption system; ${ }^{48} k_{\mathrm{f}}$ is the Freundlich constant $\left(\left(\mathrm{mg}^{1-n} \mathrm{~L}^{n}\right) \mathrm{g}^{-1}\right)$ related to relative adsorption capacity of the adsorbent; ${ }^{43} n$ is the Freundlich exponent that indicates the favourability of the adsorption process; ${ }^{\mathbf{4 1}} T$ is the absolute temperature $(\mathrm{K}), R$ is the gas constant, $k_{\mathrm{T}}\left(\mathrm{L} \mathrm{mg}^{-1}\right)$ is the equilibrium binding constant related to the maximum binding energy, $b\left(\mathrm{~kJ} \mathrm{~mol}^{-1}\right)$ is Temkin isotherm constant that relates to the adsorption heat. ${ }^{47}$

Based on the $R^{2}$ values shown in Table 4 , it is clear that $\mathrm{Zn}^{2+}$ sorption data in this case was better fitted using Freundlich and Temkin models though the value of $R^{2}$ for HAP/pectin hybrid was not as good as that of the HAP. The reason behind the poorly Freundlich and Temkin fitting of the hybrid was suggested to be related to the possible multiple sorption mechanisms (e.g. ionic exchange, surface complexation with phosphate, dissolution and re-precipitation ${ }^{\mathbf{1 0}}$ ) in the system. As is shown in Fig. 6A, a stair-like curve was clearly divided by two different ranges of equilibrium zinc concentrations: stage one with $C_{\mathrm{e}}$ less than $50 \mathrm{mg} \mathrm{L}$; stage two with $C_{\mathrm{e}}$ above $60 \mathrm{mg} \mathrm{L}^{-1}$. Lee et al. ${ }^{44}$ observed this similar two-stage sorption phenomenon at $\mathrm{pH} 5.0$ using HAP to adsorb $\mathrm{Zn}^{2+}$ and pointed out that a Langmuir type behaviour occurred when the $C_{\mathrm{e}}$ was less than $750 \mu \mathrm{M}\left(49 \mathrm{mg} \mathrm{L}^{-1}\right)$ while precipitation dominated the adsorption when the $C_{\mathrm{e}}$ exceeded $49 \mathrm{mg} \mathrm{L}^{-1}$. Given these facts, the data of hybrid alone in Fig. 6A was refitted at stage one $\left(C_{\mathrm{e}} \leq\right.$ $\left.50 \mathrm{mg} \mathrm{L}^{-1}\right)$ and stage two $\left(C_{\mathrm{e}} \geq 60 \mathrm{mg} \mathrm{L}^{-1}\right)$ separately and the results were shown in Table 5 . It turned out that the Langmuir model fit the data better when $C_{\mathrm{e}}$ was less than $50 \mathrm{mg} \mathrm{L}^{-1}$, which was almost the same as the result reported by Lee et al. ${ }^{\mathbf{4 4}}$ To further confirm this two-staged isotherm observed in Fig. 6, the $\mathrm{HAP} /$ pectin hybrid adsorbents were collected from the $3^{\text {rd }}$ replicate of the isotherm test (Fig. S1†) so that SEM-EDX analysis could be performed and the results are shown in Fig. S2. $\dagger$ The brown color depicts oxygen, green depicts carbon, light blue represents calcium, dark red represents phosphate and dark blue depicts zinc. Compared to the HAP/pectin material exposed to lower zinc concentrations $\left(C_{0} \leq 185 \mathrm{mg} \mathrm{L}^{-1}\right)$, the intensity of zinc present in the counterparts exposed to higher concentrations of zinc, show significantly higher presence of zinc as a dark blue, as shown in Fig. S2G-J. $\dagger$ The abrupt zinc color intensity changes seen in the SEM-EDX analysis corresponds with when the zinc concentration increased from 185 $\mathrm{mg} /$ to $212 \mathrm{mg} \mathrm{L}^{-1}$, which overlays with the abrupt step observed in Fig. 6. These abrupt color intensity changes observed with SEM-EDX are consistent with the two-stage, step-wise feature observed in Fig. 6, indicating a different zinc removal mechanism may occur when $C_{\mathrm{e}}$ is larger than $60 \mathrm{mg} \mathrm{L}^{-1} \cdot{ }^{44}$

\subsection{Discussion on sorption mechanism}

Mechanisms involved in zinc or other heavy metal sorption process by HAP has been well investigated and fundamental mechanisms consist of dissolution and reprecipitation; ionic exchange; and surface complexation. ${ }^{\mathbf{1 1 , 3 9 , 4 4}}$ However, the introduction of large polysaccharide or organic acids molecules into the HAP structure may change the physiochemical properties of HAP (e.g. size, morphology, cytotoxicity $\left.{ }^{\mathbf{1 5 , 4 9 , 5 0}}\right)$. 
Table 2 Sorption rate constants, experimental $\left(q_{\mathrm{e}, \mathrm{exp}}\right)$ and calculated $\left(q_{\mathrm{e}, \mathrm{cal}}\right)$ capacity of zinc sorption at equilibrium for the pseudo first and second order reaction kinetics

\begin{tabular}{|c|c|c|c|c|c|c|c|c|}
\hline \multirow[b]{2}{*}{ Adsorbents } & \multirow[b]{2}{*}{$q_{\mathrm{e}, \exp }\left(\mathrm{mg} \mathrm{g}^{-1}\right)$} & \multicolumn{3}{|c|}{ Pseudo- $1^{\text {st }}$ order } & \multicolumn{4}{|l|}{ Pseudo-2 ${ }^{\text {nd }}$ order } \\
\hline & & $k_{1}\left(\mathrm{~h}^{-1}\right)$ & $q_{\mathrm{e}, \mathrm{cal}}\left(\mathrm{mg} \mathrm{g}^{-1}\right)$ & $R^{2}$ & $k_{2}\left(\mathrm{~g}\left(\mathrm{mg}^{-1} \mathrm{~h}^{-1}\right)\right)$ & $q_{\mathrm{e}, \mathrm{cal}}\left(\mathrm{mg} \mathrm{g}^{-1}\right)$ & $h\left(\mathrm{mg}\left(\mathrm{g}^{-1} \mathrm{~h}^{-1}\right)\right)$ & $R^{2}$ \\
\hline $\mathrm{HAP} /$ pectin & 300.2 & 0.120 & 160.3 & 0.901 & 0.0038 & 303.0 & 353.4 & 0.999 \\
\hline
\end{tabular}

Therefore, it is possible that the mechanisms used to explain the heavy metal sorption by HAP may be different than the HAP/ pectin hybrid. Equilibrium $\mathrm{pH}$ after 48 hours of zinc sorption by HAP and HAP/pectin hybrid is shown in Fig. 7. The decrease in $\mathrm{pH}_{\mathrm{e}}$ values observed, coupled with the increase of $\mathrm{Zn}^{2+}$ loading on both sorbents, indicate that surface complexation mechanism occurred (eqn (9) and (10) ${ }^{39}$ ).

$$
\begin{gathered}
\equiv \mathrm{POH}+\mathrm{Zn}^{2+} \leftrightarrow \equiv \mathrm{POZn}^{+}+\mathrm{H}^{+} \\
\equiv \mathrm{CaOH}_{2}^{+}+\mathrm{Zn}^{2+} \leftrightarrow \equiv \mathrm{CaOHZn}^{2+}+\mathrm{H}^{+}
\end{gathered}
$$

For the HAP, the equilibrium $\mathrm{pH}$ was around 6 and almost remain constant with only $2.4 \%$ decrease as the $q_{\mathrm{e}}$ varied from $38.0 \mathrm{mg} \mathrm{g}^{-1}$ to $60.5 \mathrm{mg} \mathrm{g}^{-1}$. It seems that the surface complexation may not play a dominant role for the HAP we used. But it was well reported that HAP has a strong buffer ability at point of zero charge $\left(\mathrm{pH}_{\mathrm{PZC}} \sim 6.0-7.0\right)$ in a wide $\mathrm{pH}$ range from $4-10,{ }^{11,51}$ so the surface complexation induced $\mathrm{pH}$ decrease may be offset by HAP's own buffering ability. For the $\mathrm{HAP} /$ pectin hybrid, unlike the HAP, the $\mathrm{pH}_{\mathrm{e}}$, compared to the initial pH 5.0, dropped to 4.2 at $q_{\mathrm{e}}=330.4 \mathrm{mg} \mathrm{g}^{-1}$ (initial $\mathrm{Zn}^{2+}$ concentration was $263 \mathrm{mg} \mathrm{L}^{-1}$ ), indicating that the buffer balance was broken and a much stronger surface complexation occurred. Theoretically, if surface complexation was the only mechanism behind the zinc sorption by our hybrid, the final $\mathrm{pH}_{\mathrm{e}}$ would drop to 2.6 based on $q_{\mathrm{e}}=330.4 \mathrm{mg} \mathrm{g}^{-1}, C_{\text {sorbent }}=$ $0.5 \mathrm{~g} \mathrm{~L}^{-1}$ and stoichiometric ratio between adsorbed $\mathrm{Zn}^{2+}$ and released $\mathrm{H}^{+}$in eqn (9) and (10). The buffer capacity of the HAP inside the hybrid, other sorption mechanisms as well as the experimental error may be the reason to that difference between the experimental $\mathrm{pH}_{\mathrm{e}}$ and the theoretical $\mathrm{pH}_{\mathrm{e}}$ calculated above.

In order to have a further understanding of the sorption mechanism behind, the zeta potential of both sorbents was tested, and the results were exhibited in Fig. 8. The $\mathrm{pH}$ ranges from $\sim 4.5$ to $\sim 6.5$ was actually the working $\mathrm{pH}$ based on $\mathrm{pH}_{\mathrm{e}}$ data in Fig. 7 in our study. Therefore, more attention should be focused on the corresponding zeta potential in this $\mathrm{pH}$ range. It is clear that the surface of $\mathrm{HAP} /$ pectin was more negatively charged than that of the precursor HAP, illustrating the existence of a stronger electrostatic attraction in the sorption process when the hybrid was used. Gong et al. ${ }^{17}$ used pectin to modify iron oxides nanoparticles and observed similar zeta potential values. The isoelectric point for their materials was around $\mathrm{pH}$ 2.50. Unlike their iron oxide nanoparticles, both $\mathrm{HAP}$ and HAP/pectin hybrid in this work can not exist if $\mathrm{pH}$ is less than 3.0, which may explain the failure of identifying the

Table 3 Comparison of sorption capacity and conditions for the HAP/pectin hybrid in this work and other HAP or pectin-based adsorbents in the literature for zinc removal

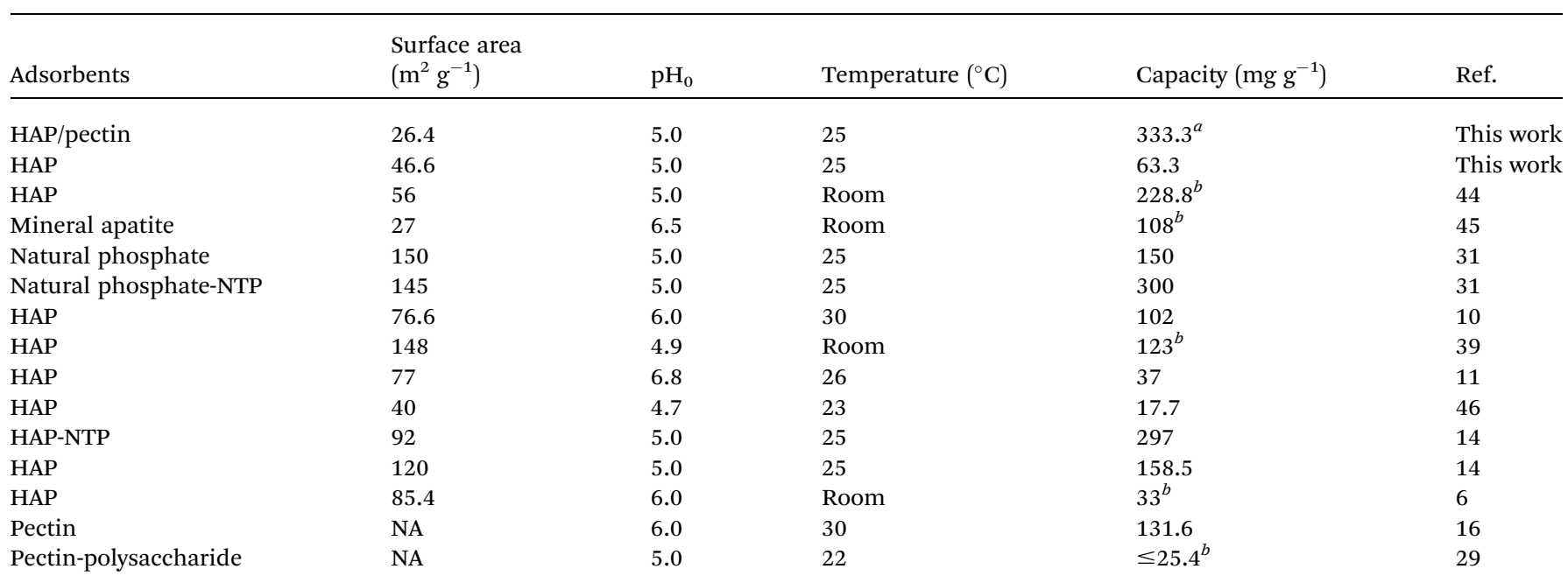

${ }^{a}$ Denotes that $333.3 \mathrm{mg} \mathrm{g}^{-1}$ was obtained based on the data fitted in Langmuir model in Table 5 . The highest experimental capacity was 330.4 mg $\mathrm{g}^{-1}$ at initial zinc concentration of $260 \mathrm{mg} \mathrm{L}^{-1}$ shown in Fig. $6 .{ }^{b}$ Denotes the maximum experimental capacity as the authors did not fit their data in Langmuir model; $\mathrm{pH}_{0}$ is the initial $\mathrm{pH}$; room is short for room temperature; NA is short for not available. 

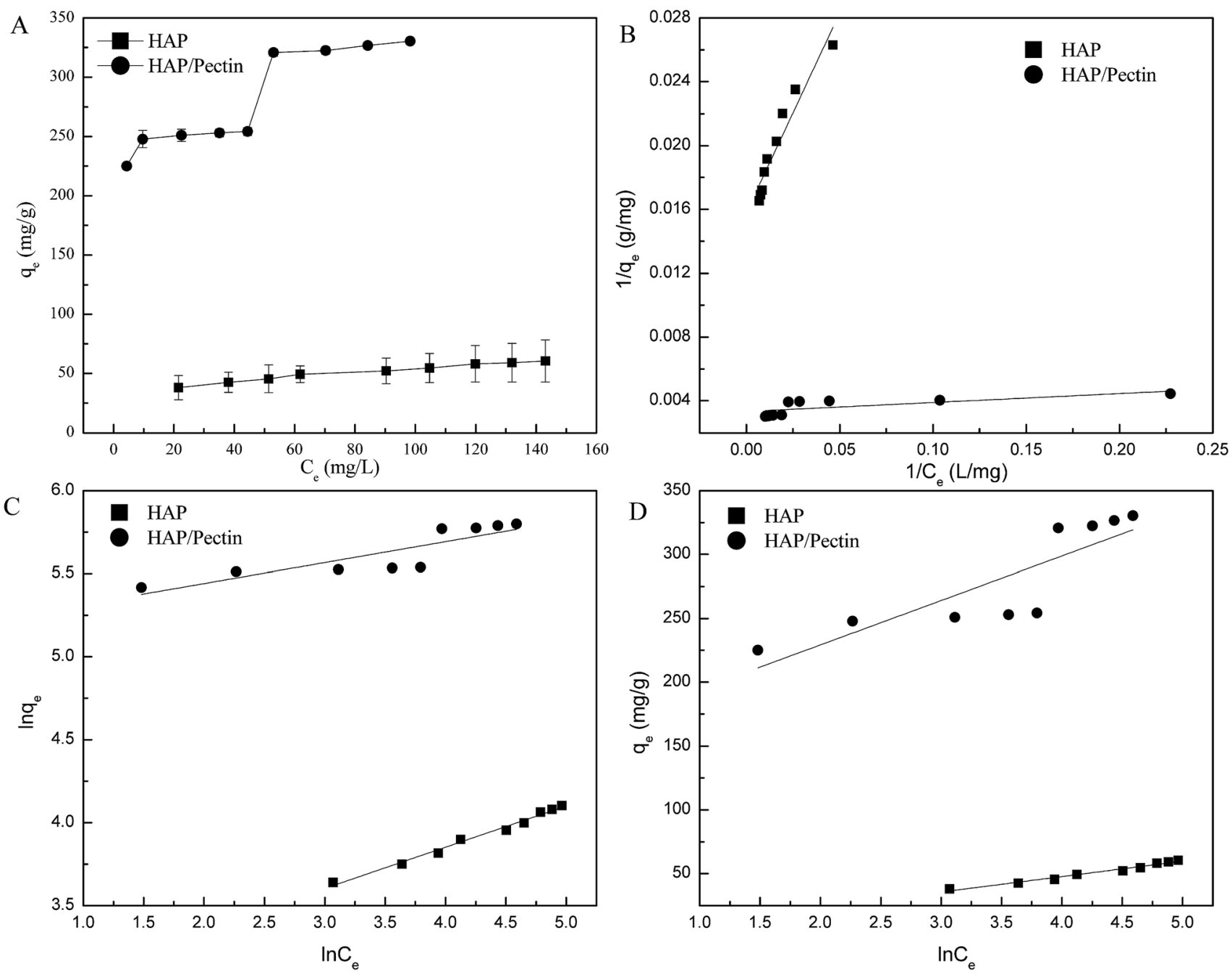

Fig. 6 Sorption isotherms of $\mathrm{Zn}^{2+}$ onto HAP and HAP/pectin. (A) The equilibrium sorption qe as a function of the equilibrium Ce; (B) the Langmuir model analysis; (C) the Freundlich model analysis; (D) Temkin model analysis.

isoelectric point of our own materials. Furthermore, the enhancement of the negative charge on the surface of the hybrid may come from the enriched oxygen groups of the pectin as reported by Li et al. ${ }^{52}$

Eqn $(11)^{6,11,39}$ describes the ion-exchange mechanism for the HAP component of the material:

$$
\begin{aligned}
x \mathrm{Zn}^{2+}+\mathrm{Ca}_{10}\left(\mathrm{PO}_{4}\right)_{6}(\mathrm{OH})_{2} & \leftrightarrow x \mathrm{Ca}^{2+} \\
& +\left(\mathrm{Zn}_{x}, \mathrm{Ca}_{10-x}\right)\left(\mathrm{PO}_{4}\right)_{6}(\mathrm{OH})_{2}
\end{aligned}
$$

Based on eqn (11), sorption of 1 mole of $\mathrm{Zn}^{2+}$ would lead to 1 mole of $\mathrm{Ca}^{2+}$ release without any $\mathrm{pH}$ change. A decrease of calcium inside the HAP/pectin adsorbent can be expected if an increase amount of zinc is sorbed. However, the equilibrium $\mathrm{pH}$ values shown in Fig. 7 decreased as the zinc removal capacity increased. Also, we did not observe a continuous decrease of calcium on the surface of HAP/pectin adsorbent when the sorbed zinc increased (see Fig. S3 $\dagger$ ). Instead, the calcium remained nearly constant when the equilibrium zinc concentration was higher than $40 \mathrm{mg} \mathrm{L}^{-1}$. Moreover, the molar concentration of

\begin{tabular}{|c|c|c|c|c|c|c|c|c|c|}
\hline \multirow[b]{2}{*}{ Adsorbents } & \multicolumn{3}{|l|}{ Langmuir } & \multicolumn{3}{|c|}{ Freundlich } & \multicolumn{3}{|l|}{ Temkin } \\
\hline & $q_{\mathrm{m}}\left(\mathrm{mg} \mathrm{g}^{-1}\right)$ & $k\left(\mathrm{~L} \mathrm{mg}^{-1}\right)$ & $R^{2}$ & $n$ & $k_{\mathrm{f}}$ & $R^{2}$ & $\begin{array}{l}b \\
\left(\mathrm{~kJ} \mathrm{~mol}^{-1}\right)\end{array}$ & $k_{\mathrm{T}}$ & $R^{2}$ \\
\hline HAP & 63.3 & 0.06 & 0.91 & 0.249 & 17.4 & 0.99 & 0.204 & 0.93 & 0.97 \\
\hline $\mathrm{HAP} /$ pectin & 300.3 & 0.59 & 0.48 & 0.126 & 179.3 & 0.72 & 0.071 & 97.9 & 0.69 \\
\hline
\end{tabular}

Table 4 Langmuir, Freundlich, and Temkin isotherm constants for the sorption of $\mathrm{Zn}^{2+}$ onto the HAP and HAP/pectin 
Table 5 The two-stage Langmuir, Freundlich, and Temkin isotherm constants for the sorption of $\mathrm{Zn}^{2+}$ onto the HAP/pectin hybrid

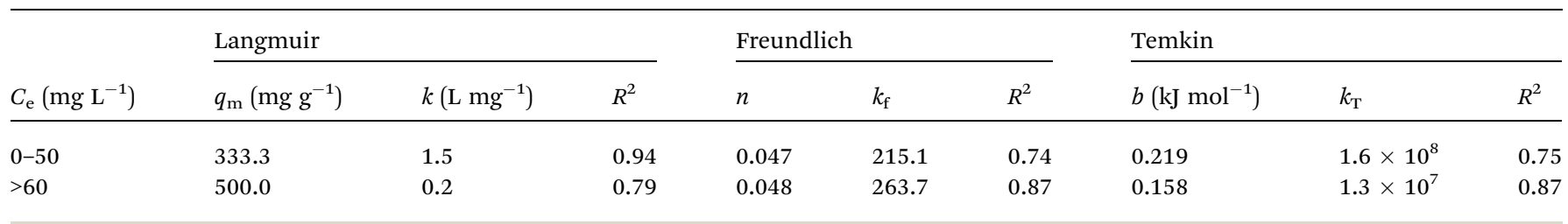

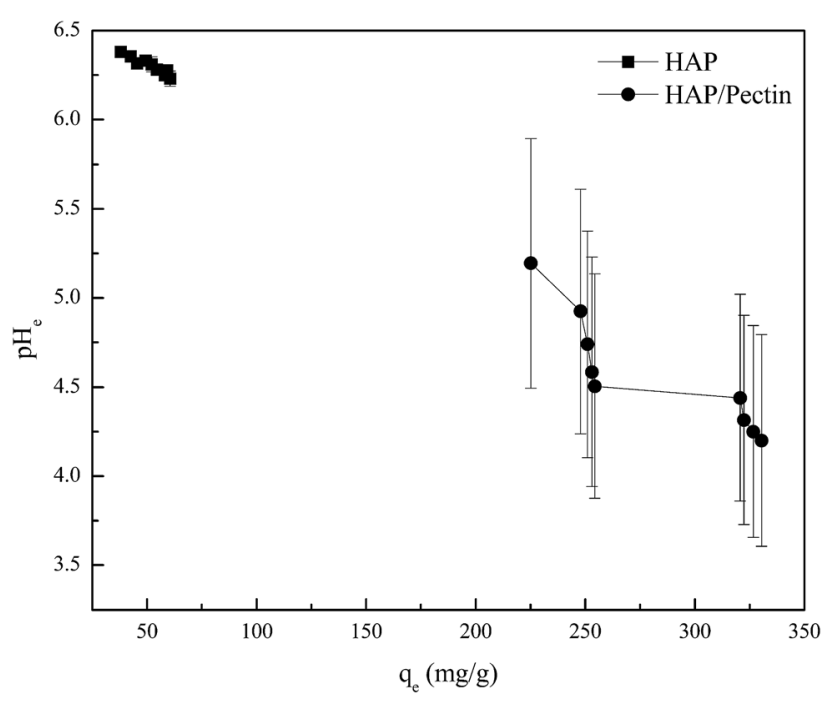

Fig. 7 he equilibrium $\mathrm{pH}\left(\mathrm{pH}_{\mathrm{e}}\right)$ vs. the corresponding equilibrium zinc sorption capacity $\left(q_{\mathrm{e}}\right)$. The $\mathrm{pH}_{\mathrm{e}}$ data was collected simultaneously during the isotherm tests shown in Fig. 6.

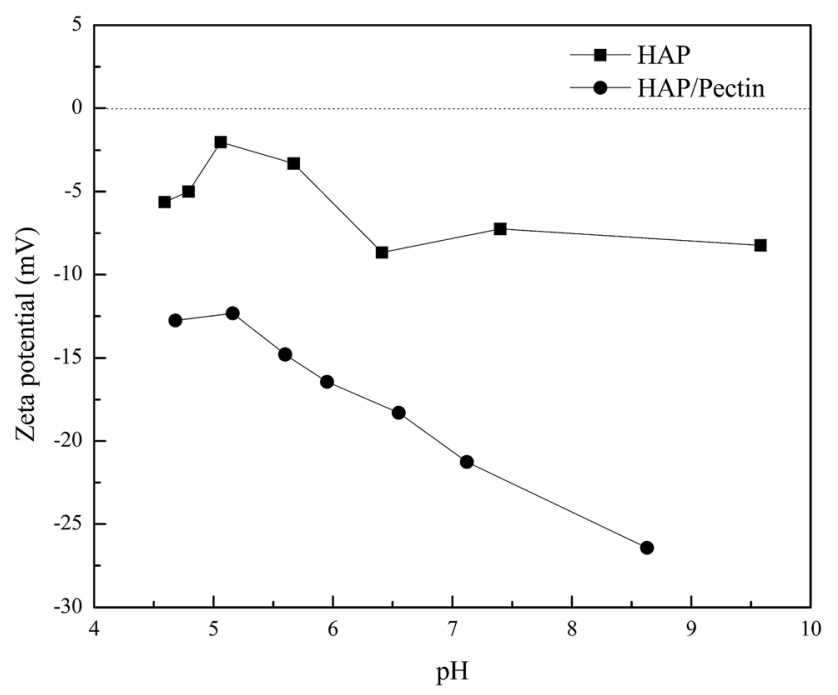

Fig. 8 Zeta potential for HAP and HAP/pectin hybrid suspended in $1 \mathrm{mM} \mathrm{KNO}_{3}$.

dissolved $\mathrm{Ca}^{2+}$ detected by AAS was higher than that of sorbed $\mathrm{Zn}^{2+}$ (see Fig. $\mathrm{S} 4 \dagger$ ). Given these observations, the ion-exchange mechanism did not occur alone. While the ion exchange mechanism contributes to calcium presence in the solution, some calcium may in part be due to dissolution of the adsorbent. When surface complexation occurs, this may impart lower pH conditions (as seen in Fig. 7), which in turn promotes the dissolution and re-precipitation process of the zinc with the adsorbent, which is described in eqn (12) and (13): ${ }^{39}$

$$
\begin{array}{r}
\mathrm{Ca}_{10}\left(\mathrm{PO}_{4}\right)_{6}(\mathrm{OH})_{2}+14 \mathrm{H}^{+} \leftrightarrow 10 \mathrm{Ca}^{2+}+6 \mathrm{H}_{2} \mathrm{PO}_{4}^{-}+2 \mathrm{H}_{2} \mathrm{O} \\
x \mathrm{Zn}^{2+}+10 \mathrm{Ca}^{2+}+6 \mathrm{H}_{2} \mathrm{PO}_{4}^{-}+2 \mathrm{H}_{2} \mathrm{O} \leftrightarrow \\
\left(\mathrm{Zn}_{x}, \mathrm{Ca}_{10-x}\right)\left(\mathrm{PO}_{4}\right)_{6}(\mathrm{OH})_{2}+x \mathrm{Ca}^{2+}+14 \mathrm{H}^{+}
\end{array}
$$

The two-staged isotherm observed in Fig. 6 might be explained in the following way: when the zinc concentration $C_{\mathrm{e}}$ $\geq 60 \mathrm{mg} \mathrm{L}^{-1}$ (the $q_{\mathrm{e}}>300 \mathrm{mg} \mathrm{g}^{-1}$ ), the $\mathrm{pH}$ dropped to 4.4-4.2 due to the mechanisms of surface complexation (see Fig. 7, eqn (9) and (10)). This acidic condition subsequently promoted the dissolution and re-precipitation process. This may be the reason why precipitation was suggested to dominate the adsorption in the previous work by Lee et $a .^{\mathbf{4 4}}$

One paradoxical fact should be noted that the surface area of the HAP/pectin hybrid was $26.4 \mathrm{~m}^{2} \mathrm{~g}^{-1}$ by BET method, only $56.7 \%$ of its parenting HAP in our work while the zinc sorption capacity of the hybrid was $300.2 \mathrm{mg} \mathrm{g}^{-1}$ (initial $\mathrm{Zn}^{2+}$ was $182.7 \mathrm{mg} \mathrm{L}^{-1}$ ) or even $330.4 \mathrm{mg} \mathrm{g}^{-1}$ (initial $\mathrm{Zn}^{2+}$ was $263 \mathrm{mg} \mathrm{L}^{-1}$ ), over 6 times than that of HAP. Saoiabi et al. ${ }^{\mathbf{1 4 3 1}}$ also observed a $3.3 \%$ or $23.3 \%$ decrease of surface area when they use $10 \%$ of NTP to modify natural phosphate or HAP to obtain the maximum zinc removal capacity. But they did not explain this paradoxical fact and instead, they tried to illustrate another phenomenon: the pore diameter of their NTP modified HAP decreased from $11 \mathrm{~nm}$ to $1.8 \mathrm{~nm}$ with the increased level of NTP used (0-10\%). They suggested that the high molecular disorder induced by the organic molecules in the apatite network as well as the surface passivation with NTP contributed to that result. In light of their work and the much larger size of pectin molecules we used in our work, it is possible to believe a smaller pore diameter (less than $1.8 \mathrm{~nm}$, even lower than $0.375 \mathrm{~nm}$ ) may be induced. Accordingly, the diameter of $\mathrm{N}_{2}$ molecule is $3.75 \AA$ (ref. 53) while that of zinc ion is 1.38-1.48 $\AA^{11,21}$ It would be reasonable to suggest the paradoxical phenomenon of the low surface area $\mathrm{HAP} /$ pectin performance is attributed to a pore diameter of our HAP/pectin hybrid less than $0.375 \mathrm{~nm}$ but higher than $0.138-0.148 \mathrm{~nm}$. The small pore size induced by pectin will prevent $\mathrm{N}_{2}$ gas molecules from entering the hybrid, leading to a poor BET surface area value while on the other hand allowing $\mathrm{Zn}^{2+}$ sorption inside the pore spaces, leading to a high loading capacity. 


\section{Conclusions}

The synthesis method of flower-like HAP/pectin hybrid sorbent has demonstrated a maximum experimental zinc sorption capacity of $330.4 \mathrm{mg} \mathrm{g}^{-1}$ when $0.5 \mathrm{~g} \mathrm{~L}^{-1}$ sorbent was used to treat $260 \mathrm{mg} \mathrm{L}^{-1} \mathrm{Zn}^{2+}$ solution at $25 \pm 1{ }^{\circ} \mathrm{C}$ with an initial $\mathrm{pH}$ 5.0. The characterization of the hybrid HAP/pectin possessed brushite, monetite and carbonates. The zinc sorption kinetics are best described as a pseudo second order model. A two-stage isotherm curve was observed, which best fits the results with a Langmuir model fitting best when the equilibrium zinc concentration was less than $50 \mathrm{mg} \mathrm{L}$; otherwise, the Freundlich model fits best at zinc concentrations above $60 \mathrm{mg} \mathrm{L}^{-1}$, illustrating different mechanisms may occur at different concentrations of aqueous zinc. The $\mathrm{pH}$ monitoring and the zeta potential test indicate that at least surface complexation, electrostatic attraction were involved in the zinc sorption process.

This study demonstrated a simple and low-cost method to convert HAP into a highly effective zinc sorbent. Further investigations will appraise the operation, and recycling of the hybrid adsorbent material.

\section{Conflicts of interest}

The authors declare no conflicts of interest within this work.

\section{Acknowledgements}

The authors would like to thank Dr Adam Redding and Kyle Trewitz from Evoqua Water Technologies LLC for the BET surface area characterization. The authors would like to thank Lehigh University for supporting this work.

\section{References}

1 M. K. Uddin, Chem. Eng. J., 2017, 308, 438-462.

2 S. Bolisetty and R. Mezzenga, Nat. Nanotechnol., 2016, 11, 365-371.

3 S. Sarkar, P. K. Chatterjee, L. H. Cumbal and A. K. SenGupta, Chem. Eng. J., 2011, 166, 923-931.

4 R. Camarillo, J. Llanos, L. Garcia-Fernandez, A. Perez and P. Canizares, Sep. Purif. Technol., 2010, 70, 320-328.

5 F. L. Fu and Q. Wang, J. Environ. Manage., 2011, 92, 407-418. 6 M. Peld, K. Tonsuaadu and V. Bender, Environ. Sci. Technol., 2004, 38, 5626-5631.

7 P. Chand and Y. B. Pakade, Environ. Sci. Pollut. Res., 2015, 22, 10919-10929.

8 T. A. Salah, A. M. Mohammad, M. A. Hassan and B. E. ElAnadouli, J. Taiwan Inst. Chem. Eng., 2014, 45, 1571-1577.

9 J. J. Li, H. Sun, D. Sun, Y. L. Yao, F. L. Yao and K. D. Yao, Carbohydr. Polym., 2011, 85, 885-894.

10 R. R. Sheha, J. Colloid Interface Sci., 2007, 310, 18-26.

11 Y. P. Xu, F. W. Schwartz and S. J. Traina, Environ. Sci. Technol., 1994, 28, 1472-1480.

12 A. Bengtsson, A. Shchukarev, P. Persson and S. Sjoberg, Geochim. Cosmochim. Acta, 2009, 73, 257-267.
13 M. S. Fernando, R. M. de Silva and K. M. N. de Silva, Appl. Surf. Sci., 2015, 351, 95-103.

14 S. Saoiabi, A. Gouza, H. Bouyarmane, A. Laghzizil and A. Saoiabi, J. Environ. Chem. Eng., 2016, 4, 428-433.

15 W. C. Fang, H. Zhang, J. W. Yin, B. G. Yang, Y. B. Zhang, J. J. Li and F. L. Yao, Cryst. Growth Des., 2016, 16, 1247-1255.

$16 \mathrm{M}$. Y. Khotimchenko, E. A. Kolenchenko and Y. S. Khotimchenko, J. Colloid Interface Sci., 2008, 323, 216-222.

17 J. L. Gong, X. Y. Wang, G. M. Zeng, L. Chen, J. H. Deng, X. R. Zhang and Q. Y. Niu, Chem. Eng. J., 2012, 185, 100-107.

18 F. Munarin, P. Petrini, G. Barcellona, T. Roversi, L. Piazza, L. Visai and M. C. Tanzi, Mater. Sci. Eng., C, 2014, 45, 154161.

19 F. Munarin, P. Petrini, R. Gentilini, R. S. Pillai, S. Dire, M. C. Tanzi and V. M. Sglavo, Int. J. Biol. Macromol., 2015, 72, 199-209.

20 D. Gopi, K. Kanimozhi and L. Kavitha, Spectrochim. Acta, Part A, 2015, 141, 135-143.

21 Z. Elouear, J. Bouzid, N. Boujelben, M. Feki, F. Jamoussi and A. Montiel, J. Hazard. Mater., 2008, 156, 412-420.

22 G. McKay and J. F. Porter, J. Chem. Technol. Biotechnol., 1997, 69, 309-320.

23 Z. H. Ding, X. Hu, Y. S. Wan, S. S. Wang and B. Gao, J. Ind. Eng. Chem., 2016, 33, 239-245.

24 M. Hua, S. J. Zhang, B. C. Pan, W. M. Zhang, L. Lv and Q. X. Zhang, J. Hazard. Mater., 2012, 211, 317-331.

25 A. Alfarra, E. Frackowiak and F. Beguin, Appl. Surf. Sci., 2004, 228, 84-92.

26 M. Erdemoglu and M. Sarikaya, J. Colloid Interface Sci., 2006, 300, 795-804.

27 I. Smiciklas, A. Onjia, S. Raicevic, D. Janackovic and M. Mitric, J. Hazard. Mater., 2008, 152, 876-884.

28 A. Jakobik-Kolon, A. Szybaj, K. Mitko and J. Bok-Badura, Molecules, 2017, 22, 2274.

29 A. Jakobik-Kolon, J. Bok-Badura, K. Karon, K. Mitko and A. Milewski, Carbohydr. Polym., 2017, 169, 213-219.

30 D. P. Minh, H. Sebei, A. Nzihou and P. Sharrock, Chem. Eng. J., 2012, 198, 180-190.

31 S. Saoiabi, S. El Asri, A. Laghzizil, A. Saoiabi, J. L. Ackerman and T. Coradin, Chem. Eng. J., 2012, 211, 233-239.

32 C. C. Ribeiro, I. Gibson and M. A. Barbosa, Biomaterials, 2006, 27, 1749-1761.

33 Y. Suetsugu, K. Hirota, K. Fujii and J. Tanaka, J. Mater. Sci., 1996, 31, 4541-4544.

34 S. Meski, S. Ziani, H. Khireddine, S. Boudboub and S. Zaidi, J. Hazard. Mater., 2011, 186, 1007-1017.

35 A. Z. Alshemary, M. Akram, Y. F. Goh, M. R. A. Kadir, A. Abdolahi and R. Hussain, J. Alloys Compd., 2015, 645, 478-486.

36 X. D. Kong, F. Z. Cui, X. M. Wang, M. Zhang and W. Zhang, J. Cryst. Growth, 2004, 270, 197-202.

37 B. Fu, Q. Shen, W. Qian, Y. Zeng, X. Sun and M. Hannig, J. Mater. Sci.: Mater. Med., 2005, 16, 827-831.

38 A. Balaria and S. Schiewer, Sep. Purif. Technol., 2008, 63, 577581. 
39 H. Sebei, D. P. Minh, A. Nzihou and P. Sharrock, Appl. Surf. Sci., 2015, 357, 1958-1966.

40 B. Alyuz and S. Veli, J. Hazard. Mater., 2009, 167, 482-488.

41 Y. B. Yan, Y. P. Wang, X. Y. Sun, J. S. Li, J. Y. Shen, W. Q. Han, X. D. Liu and L. J. Wang, Appl. Surf. Sci., 2014, 317, 946-954. 42 Y. S. Ho and G. McKay, Process Saf. Environ. Prot., 1998, 76, 332-340.

43 H. Wang, X. Z. Yuan, Y. Wu, H. J. Huang, G. M. Zeng, Y. Liu, X. L. Wang, N. B. Lin and Y. Qi, Appl. Surf. Sci., 2013, 279, 432-440.

44 Y. J. Lee, E. J. Elzinga and R. J. Reeder, Environ. Sci. Technol., 2005, 39, 4042-4048.

45 X. B. Chen, J. V. Wright, J. L. Conca and L. M. Peurrung, Environ. Sci. Technol., 1997, 31, 624-631.

46 K. Viipsi, S. Sjoberg, K. Tonsuaadu and A. Shchukarev, J. Hazard. Mater., 2013, 252, 91-98.
47 D. Doulia, C. Leodopoulos, K. Gimouhopoulos and F. Rigas, J. Colloid Interface Sci., 2009, 340, 131-141.

48 O. Rahmanian, M. Dinari and M. K. Abdolmaleki, Appl. Surf. Sci., 2018, 428, 272-279.

49 N. H. de Leeuw and J. A. L. Rabone, CrystEngComm, 2007, 9, 1178-1186.

50 W. P. Feng, G. F. Liang, S. Y. Feng, Y. M. Qi and K. Y. Tang, Int. J. Biol. Macromol., 2015, 74, 218-223.

51 I. Smiciklas, A. Onjia and S. Raicevic, Sep. Purif. Technol., 2005, 44, 97-102.

52 J. J. Li, D. W. Zhu, J. W. Yin, Y. X. Liu, F. L. Yao and K. D. Yao, Mater. Sci. Eng., C, 2010, 30, 795-803.

53 National Physical Laboratory, http:// www.kayelaby.npl.co.uk/general_physics/2_2/2_2_4.html, accessed 2017. 